\title{
A Comparative Study of Low-Profile and Regular Type Totally Implantable Venous Access Devices in Patients with Malignant Tumors: Retrospective Analysis of 4501 Implantations
}

\author{
Ilkay AKMANGIT ${ }^{1}$, Dogan DEDE ${ }^{1}$, Ergun DAGLIOGLU ${ }^{2}$, Bige SAYIN ${ }^{1}$, \\ Ahmet PEKER ${ }^{3}$, Dogan UNCU ${ }^{4}$, Nurullah ZENGIN ${ }^{4}$ \\ ${ }^{1}$ Ankara Numune Training and Research Hospital, Interventional Radiology Clinics \\ ${ }^{2}$ Ankara Numune Training and Research Hospital, Neurosurgery Clinics \\ ${ }^{3}$ Ankara University Faculty of Medicine, Department of Radiology \\ ${ }^{4}$ Ankara Numune Training and Research Hospital, Medical Oncology Clinics, Ankara, TURKEY
}

\begin{abstract}
The purpose of this study was to evaluate safety and efficacy of image-guided radiological totally implantable venous access devices with special reference to rate of skin complications of both regular and low-profile types. 4395 patients were referred to Interventional Radiology Unit between March 2003-September 2013. 4501 implantations of totally implantable venous access device were performed in patients under sonography and fluoroscopy. During this period 2299 regular-type and 2202 low-profile type totally implantable venous access devices were used. Success rate, periprocedural early and long-term complications were evaluated. Periprocedural and early complications of totally implantable venous access devices included $16(0.4 \%)$ arterial punctures, $101(2.2 \%)$ minor hematoma, 1 (\%0.02) disconnection of the catheter, $4(0.09 \%)$ septum separation, 38(0.8\%) minor erythema-pain and tenderness, $23(0.5 \%)$ short term fever without bacteriemia and $25(0.6 \%)$ inversion of the port. Late complications included 6(0.1\%) cellulitis, $8(0.2 \%)$ bacteriemia and sepsis, 305 (6.8\%) venous thrombosis, $62(1.4 \%)$ catheter thrombosis, $6(0.1 \%)$ catheter migration and $3(0.07 \%)$ catheter fracture. A total of 53 (1.18\%) skin perforation were seen. There was statistically significant difference between regular and low-profile totally implantable venous access devices particularly in patients with normal and thinner subcutaneous fat tissue ( $p=0.024$ and $<0.001$ respectively). The present study is the largest series in the literature in patients with malignant tumors. Image-guided radiological totally implantable venous access device placement is safe and reliable method with a low risk of complications and the results of this study further justify the use of low profile totally implantable venous access device based on lower skin complications.
\end{abstract}

Keywords: Port, TIVAD, Low-profile, Regular, Skin perforation

\section{ÖZET}

Malign Tümörlü Olgularda Düşük Profilli ve Standard Tip TiVEC kullanımının Karşılaştırmalı Çalışması: 4501 Olgunun Retrospektif Analizi

Bu çalışmanın amacı radyolojik görüntüleme eșliğinde yerleştirilen, standart ve düşük profilli, tamamen implante edilebilir venöz erişim cihazlarının cilt komplikasyonları yönünden güvenirlik ve etkinliğinin değerlendirilmesiydi. Mart 2003 ve Eylül 2013 tarihleri arasında 4395 hasta Girişimsel Radyoloji ünitesine başvurdu. Bu hastalara ultrasonografi ve floroskopi eşliğinde 4501 tamamen implante edilebilir venöz erişim cihazı yerleştirildi. Bu süre içinde 2299 standard tipte, 2202 düşük profilli tamamen implante edilebilir venöz erişim cihazı kullanıldı. Başarı oranı, işlem sırasında, erken ve geç komplikasyonlar değerlendirildi. Tamamen implante edilebilir venöz erişim cihazı yerleştirilmesi sırasında gelişen erken dönem komplikasyonlar arteriel giriş 16 (\%0.4), minör hematom 101 (\%2.2), kateter ayrıması 1 (\%0.02), septum ayrıması 4 (\%0.09), minör eritem-ağrı ve hassasiyet 38 (\%0.8), bakteriyemi olmaksızın kısa süren ateş 23 (\%0.5) ve portun ters dönmesi 25 (\%0.6) olarak sıralandı. Geç komplikasyonlar selülit 6 (\%0.1), bakteriyemi ve sepsis 8 (\% 0.2), venöz trombozis 305 (\%6.8), kateter trombozu 62 (\%1.4), kateter migrasyonu 6 (\%0.1) ve kateter kırılması 3 (\%0.07) olmuştur. Kronik dönemde toplam 53 cilt perforasyonu (\%1.18) görüldü. Özellikle normal ve ince subkutan yağ dokusu olan hastalarda standard ve düşük profilli tamamen implante edilebilir venöz erişim cihazı kullanımı arasında istatistiksel olarak anlamlı fark mevcuttu (sırasıyla $p=0.024$ ve $<0.001$ ). Bu çalışma malign tümörlü hastalarda tamamen implante edilebilir venöz erişim cihazı kullanımı ile ilgili literatürdeki en geniş seridir. Radyolojik görüntüleme eșliğinde tamamen implante edilebilir venöz erişim cihazı yerleştirilmesi düşük komplikasyon riski ile güvenilir bir metottur. Bu çalışma ayrıca düşük profilli tamamen implante edilebilir venöz erişim cihazı kullanımının daha düşük cilt komplikasyonlarına yol açtığını ortaya koymuştur.

Anahtar Kelimeler: Port, Tamamen implante edilebilir venöz erişim cihazı, Düşük profil, Regüler, Cilt perforasyonu 


\section{INTRODUCTION}

Long term vascular access is mandatory for cancer patients who are in need of repeated administration of chemotherapeutics or antibiotics. ${ }^{1,2}$ Silicone-based tunneled catheters were the pioneer material in the market used for prolonged intravascular infusions and blood sampling. ${ }^{3}$ These catheters were then revised by Hickman et al in $1979 .{ }^{4}$ Niederhuber et al was the first to report a totally implantable venous access device (TIVAD) placement in 1982. ${ }^{5}$

TIVAD and tunnelled catheter implantation with cutdown technique or blind puncture using anatomical landmarks was first described by general surgeons. ${ }^{6}$ After the introduction of peel-away sheaths, radiologically guided TIVAD and tunneled catheter implantation was introduced to the market. ${ }^{7}$ Compared with the other tunneled catheters, TIVADs provided a better cosmetic result, more comfortable postprocedural period and low long-term complication rate. ${ }^{1,7}$ Meanwhile, TIVADs are also convenient for administration of other routine medications, daily nutrient supplements or blood sampling. For long term central venous access, TIVADs implantation under image guidance by interventional radiologists was described as a safe and effective alternative to surgical technique., ${ }^{8,9}$ Two types of TIVADs are usually preferred in adults named as regular and low-profile. The difference between these 2 types is the size in height, base diameter and septum size. In this retrospective study, we present the technical success and complication rates of image-guided radiological TIVAD implantation procedures. To our knowledge, this is the largest series reported in the literature and we point out the importance of low-profile Type (LT) TIVADs are associated with a decreased rate of skin perforation.

\section{MATERIAL AND METHOD}

\section{Patient Selection}

4395 patients who underwent image-guided radiological TIVAD placement at Interventional Radiology Section of Ankara Numune Education and Research Hospital between March 2003 and February 2013 were included in the study. The group consisted of a slight preponderance of females (2309 female 52.5\% versus 2086 male $47.5 \%$ ) with a mean age of 49.6 years (Range 18 to 84 years). Malignancies encountered were hematologic (1589 patients), gastrointestinal (1375 patients), breast carcinoma (557 patients), genitourinary (634 patients) and other malignancies (271 patients) in the decreasing order of frequency.
In the early years of this 10 year period, we used Regular Type (RT) of TIVAD (Port-A-Cath Smiths Medical, London, UK) in all patients. But with the increasing experience of the unit staff about TIVAD usage and high skin necrosis ratio with RT TIVAD, we changed our choice of TIVAD. If the subcutaneous fat tissue thickness was significant, RT TIVAD was preferred. If the subcutaneous fat tissue thickness was normal or thinner, LT TIVAD was used. The respective height, base diameter and septum size of the RT TIVAD and LT TIVAD are as follows: height 14.7 vs $11.5 \mathrm{~mm}$, base diameter $30.5 \mathrm{vs} 25 \mathrm{~mm}$ and septum size 11.4 vs $9.5 \mathrm{~mm}$. Both TIVADs are easily inserted using the same technique except for a larger pocket which is required in cases of RT TIVAD.

\section{Implantation technique}

A complete blood count and INR measurement were performed for every patient the day before the procedure and patients with a platelet count over 50000 $\mathrm{mm}^{3}$ and INR rates lower than 1.5 were included. Patients with INR rate over 1.5 received fresh frozen plasma before the implantation. All patients received a single intravenous dose of 1 gram cefazolin an hour before the procedure and continued up to 3 days for prophylaxis.

All TIVAD implantations were performed in the Interventional Radiology Suite by interventional radiologists. Before the implantation, an ultrasonographic evaluation of the internal jugular veins (IJV) was performed to confirm the patency and to identify a preexisting venous trombosis. Right IJV was the preferred entry site because of its straight course and short distance to right atrium, however left IJV was preferred as a second choice due to patency problems and anatomical limitations. In case of bilateral small or trombosed IJVs, subclavian veins (SCV) were used for venous access. Transfemoral route was used for TIVAD implantation when all the routes described above were inaccessible.

The skin was prepared with chlorhexidine for a standard sterile technique. A local anesthetic $(20 \mathrm{ml}$ prilocain) was injected to the area of TIVAD implantation and venous puncture. Venous puncture was performed under the guidance of ultrasonography with an $18 \mathrm{G}$ needle using the Seldinger technique. A 0,035 -inch guidewire was inserted into IJV and the tip of the wire was advanced to the vena cava inferior via vena cava superior and right atrium. The peel away sheath was meticulously placed over the guidewire. A suf- 
ficient size of subcutaneous port pocket was created in the infraclavicular area and catheter was tunneled from the port pocket to the venous access site with the aid of trochar. The port chamber was connected to the catheter and checked for leaks just before port implantation to the port pocket. After the decision of catheter length that would remain in the venous lumen under fluoroscopy, the catheter was placed to the high atrial region via peel away sheath. The port was accessed with a $22 \mathrm{G}$ Huber needle and flushed with 2-5 $\mathrm{ml}$ of $100 \mathrm{U} / \mathrm{ml}$ heparinized saline solution after the procedure. If the port pocket was noticed too loose or wide, the port chamber was fixed by a simple suture to the fascia underneath. The tip of the catheter, a possible kink at the puncture site or pneumothorax was evaluated with a postprocedure chest X-ray. TIVAD implantation was completed with a few interrupted skin sutures.

All patients were informed about the local infection signs like fever, swelling and redness at the access site and were recommended to contact their primary physician as soon as possible.

\section{Follow-up}

TIVADs were used for intravenous access by medical staff immediately after implantation in majority of the cases. Access site was subjected to a daily care and chlorhexidine was used for local antisepsis just before use. A 22-gauge noncoring Huber needle (Gripper needle, Smiths Healthcare Manufacturing S.A. de C.V., Mexico) was inserted into the TIVAD. Heparinized saline was injected to control the patency of the catheter or subcutaneous leakage. A semi-permeable dressing was used to cover the needle and the needle was changed every 5 days when longer infusions were required. Heparinized saline flush at dilution of $100 \mathrm{U} / \mathrm{ml}$ was used after every access or monthly during times of port inactivity. X-ray follow-up was obtained every 2 months to confirm the location of catheter tip. All complications were noted in accordance with the recommendations of the Society of the interventional Radiology (SIR). Complications were classified as periprocedural ( $<24$ hours after implantation), early ( 1 to 30 days after the procedure) and late ( $>30$ days after).

All data were collected from the hospital records and the end point of the study was TIVAD removal or death of the patient.

\section{Statistical Analysis}

Difference between groups in terms of categorical data was evaluated by Chi-Square test or Fisher's Exact test where applicable. Bonferroni correction was applied to control type I error. P value less than 0.05 was considered significant.

\section{RESULTS}

A total of 4501 TIVADs were implanted in 4395 patients. Reimplantantion was required in 106 patients due to complications: venous thrombosis (47 patients), skin perforation (45 patients), catheter migration (6 patients), catheter fracture (3 patients) and cellulitis (1 patient). The total follow-up period was 2.484.552 catheter days (range 5-1855 days; mean 552 days). Correct venous puncture site was achieved in 4358 of 4501 implantations with the aid of ultrasonography and primary technical success rate was detected as $96.8 \%$. Alternative venous access sites were used for puncture in 143 TIVAD implantations due to primary site problems such as superior vena cava thrombosis, inability to puncture due to obesity or low central venous pressure. The overall secondary technical success rate for TIVAD implantation at alternative sites was $100 \%$.

\section{Periprocedural Complications}

All periprocedural complications were summarized in Table 1. Even though all venous punctures were achieved under ultrasonography guidance, an accidental arterial puncture occurred in 16 implantations and manual local compression was immediately applied for treatment. A minor oozing of blood was noted at the incision site in 92 cases which were treated with manual compression without any further intervention. A minor hematoma developed around the TIVAD pocket in 101 (2.2\%) cases which were asymptomatic. A mechanical complication occurred in one patient due to disconnection of the catheter from its reservoir part at the first injection. In this patient the catheter was retrieved under fluoroscopy by a goose-neck snare via the right femoral vein without any complication and another port catheter was implanted. Among the type of complications presented, minor hematoma was significantly more frequent with regular type of TIVAD ( $\mathrm{p}<0.001)$.

Periprocedural complications like pneumothorax, hemothorax, air embolism or major hematoma were not observed in any patient. 
International Journal of Hematology and Oncology

\begin{tabular}{|c|c|c|c|c|}
\hline Complications & $\begin{array}{l}\text { RT TIVAD } \\
(\mathrm{n}=2299)\end{array}$ & $\begin{array}{l}\text { LT TIVAD } \\
(\mathrm{n}=2202)\end{array}$ & Total & $\mathrm{p}$ \\
\hline \multicolumn{5}{|c|}{ Periprocedural complications of TIVADs } \\
\hline Arterial punctures & $10(0.4 \%)$ & $6(0.3 \%)$ & $16(0.4 \%)$ & 0.360 \\
\hline Minor hematoma & $72(3.1 \%)$ & $29(1.3 \%)$ & $101(2.2 \%)$ & $<0.001$ \\
\hline \multicolumn{5}{|l|}{ Early complications of TIVADs } \\
\hline Disconnection of the Catheter & 0 & $1(0.05 \%)$ & $1(0.02 \%)$ & 0.489 \\
\hline TIVAD septum separation & $1(0.04 \%)$ & $3(0.1 \%)$ & $4(0.09 \%)$ & 0.364 \\
\hline Minor erythema, pain and tenderness & $21(0.9 \%)$ & $17(0.8 \%)$ & $38(0.8 \%)$ & 0.604 \\
\hline Fever without bacteriemia & $10(0.4 \%)$ & $13(0.6 \%)$ & $23(0.5 \%)$ & 0.465 \\
\hline Inversion of TIVAD & $6(0.3 \%)$ & $19(0.9 \%)$ & $25(0.6 \%)$ & 0.0066 \\
\hline \multicolumn{5}{|l|}{ Late complications of TIVADs } \\
\hline Cellulitis & $3(0.1 \%)$ & $3(0.1 \%)$ & $6(0.1 \%)$ & 1.000 \\
\hline Death due to bacteriemia and sepsis & $3(0.1 \%)$ & $5(0.2 \%)$ & $8(0.2 \%)$ & 0.499 \\
\hline Venous thrombosis & 139 (6.0%) & $166(7.5 \%)$ & 305 (6.8\%) & 0.046 \\
\hline Catheter lumen thrombosis & $27(1.2 \%)$ & $35(1.6 \%)$ & $62(1.4 \%)$ & 0.232 \\
\hline Catheter migration & 2 (0.09\%) & $4(0.2 \%)$ & $6(0.1 \%)$ & 0.443 \\
\hline Catheter fracture & 2 (0.09\%) & $1(0.05 \%)$ & $3(0.07 \%)$ & 1.000 \\
\hline Skin perforation & 34 (1.5\%) & 19 (0.9\%) & 53 (1.20\%) & 0.055 \\
\hline
\end{tabular}

\section{Early Postprocedural Complications}

Early complications are summarized in Table 1. TIVAD septum was seperated from the reservoir part in $4(0.09 \%)$ cases. These TIVAD's were all replaced completely with a new one. Minor erythema, pain and tenderness were observed at the port pocket area without any purulant discharge in $38(0.8 \%)$ patients. Another $23(0.5 \%)$ patients had short term fever below $38^{\circ} \mathrm{C}$ without bacteriemia. These patients were managed successfully with the administration of appropriate antibiotics. In $25(0.6 \%)$ patients, TIVAD's had revised because of the inversion of the port catheter in the pocket. With regard to the early complications, inversion of TIVAD was more frequent with LT TIVAD $(\mathrm{p}=0.007)$.

\section{Late Postprocedural Complications}

All late complications were summarized on Table 1. Cellulitis was noted in $6(0.1 \%)$ patients and managed with wide spectrum antibiotics. Removal of TIVAD was necessary just in one patient due to antibiotic resistance. Bacteriemia and sepsis developed in $8(0.2 \%)$ patients with hematologic malignancies. Blood cultures taken from TIVAD revealed Staphylococcus epidermidis in 5, Staphylococcus aureus, Candida albicans and Escherichia coli in the remaining cases. All of these patients were lost despite aggressive antibiotherapy. On follow-up, venous thrombosis developed in 305 (6.8\%) patients and all received low molecular weight heparin. A total of 47 TIVAD were removed due to progression of venous thrombosis.

Skin perforations were seen in $53(1.18 \%)$ patients totally. With RT TIVAD, skin perforation ratio of the patients with the thicker, normal and thinner subcutaneous fat tissue thickness were respectively $0.6 \%$, $2.1 \%$ and $8.9 \%$. LT TIVAD caused significantly lower skin perforation ratio than the RT TIVAD; $0 \%$, $0.8 \%$ and $1.2 \%$ respectively. Except skin perforation, all other short and long-term complication rates were similar between RT and LT TIVADs (Table 2).

Other late complications were catheter lumen thrombosis in $62(1.4 \%)$, catheter migration in $6(0.1 \%)$ and catheter fracture in $3(0.09 \%)$ cases. Venous thrombosis was encountered more frequently in LT TIVAD and the difference was statistically significant. As noted in table 2 skin perforation was similar for both RT and LT TIVADs. It is more common with the use of RT TIVAD in thinner patients $(\mathrm{p}<0.001)$. When the subgroups were compared, statistically significant difference was noted in skin perforation in normal and thinner individuals $(\mathrm{p}=0.024 *$ and $\mathrm{p}<0.001 *$ respectively).

\section{DISCUSSION}

Current improvements in medical oncology and anticancer drugs necessitate a safe long-term central ve- 
International Journal of Hematology and Oncology

Table 2. Distribution of used TIVADs and Skin perforation data

\begin{tabular}{|llll}
\hline & Skin Perforation/RT TIVAD & Skin Perforation/LT TIVAD & P* Value \\
\hline Thicker & $9 / 1609(0.6 \%)$ & $0 / 257(0 \%)$ & 0.620 \\
Normal & $11 / 533(2.1 \%)$ & $8 / 1052(0.8 \%)$ & 0.024 \\
Thinner (cachectic) & $14 / 157(8.9 \%)$ & $11 / 893(1.2 \%)$ & $<0.001$ \\
P Value & $<0.001$ & 0.151 &
\end{tabular}

*Bonferroni correlation was applied

nous access for administration of intravenous chemotherapy, parenteral nutrition, blood transfusion, fluid replacement or frequent blood sampling in the majority of the patients. ${ }^{2,8,10-12} \mathrm{~A}$ central venous access gives a great advantage to cancer patients with unrestricted mobility and improved quality in daily activities or reducing the anxiety associated with repeated peripheral venous punctures. ${ }^{2,4,8,10-15}$

After its first introduction by Niederhuber et al in 1982, multiple reports on TIVAD implantation were published pointing to its safety or benefit for longterm chemotherapy and central venous access. ${ }^{16,17,18,19}$ At the beginning, TIVADs were implanted by general surgeons who are familiar to cutdown or landmark techniques. ${ }^{6}$ Furthermore, the discovery of peel-away sheaths allowed TIVAD implantation with Seldinger technique. ${ }^{7,20}$ In literature, surgical TIVAD implantation using Seldinger/landmark/cutdown techniques with the SCV or IJV had a complication rate varying between $4 \%$ and $24.6 \%$ (18,21-26). Image guidance with fluoroscopy and ultrasound for IJV or SCV puncture provided a higher technical success rate and low risk of periprocedural complications compared to the surgical technique. ${ }^{13,23,27-31}$ Right IJV is the preferred site for TIVAD implantation by the interventional radiologists because of its straight course that reduces catheter complications like thrombosis and low risk of catheter pinch-off phenomen between the first rib and the clavicle. ${ }^{32-35}$ Femoral veins are usually not preferred for puncture however it might be advantageous in conditions like tumoral involvement or stenosis/thrombosis of superior vena cava and puncture problems related to low central venous pressure or obesity. ${ }^{32}$

Studies on ultrasound-guided vessel punctures demonstrated success rates over $90 \% .^{30,36-38}$ In the present study, ultrasonographic evaluation done before the procedure or its guidance during venous puncture allowed a primary technical success rate as high as $96.8 \%$. In 138 of 143 failed patients, a successful venous puncture could not be achieved due to low central venous pressure or obesity. In the remaining 5 patients, successful venous puncture was possible however a guidewire could not be propogated because of chronic occlusion of the superior vena cava. Alternative sites like left IJV, bilateral SCV or femoral veins were preferred for all failed primary venous punctures with a secondary technical success rate of $100 \%$.

TIVADs which were implanted with a landmark/ seldinger or cutdown technique of the SCV were associated with higher complication rates. . $^{9,2,21,22,26}$ Subclavian vein puncture was reported to be associated with pneumothorax $(0.6-4.3 \%)^{2,8,39,40}$ and inadvertant arterial puncture $(2.4 \%)^{9,21,40}$ in surgical series. It is evident that these complications were decreased prominently with ultrasound-guided venous punctures. ${ }^{13,20,41}$ Teichgräber et al reported an accidental arterial puncture in $0.16 \%$ of 3160 patients undergoing TIVAD implantation. ${ }^{19}$ In the present study, an inadvertant arterial puncture was reported in $16(0.3 \%)$ patients and easily controlled by local pressure. Any other periprocedural complication like pneumothorax, hemothorax, nerve injury, arrhytmia or air embolism were not recorded.

The optimal position for port catheter tip is at the cavoatrial junction. This position of tip provides a decreased risk of postprocedural thrombotic complications and inevitable catheter dysfunction during aspiration and infusion. ${ }^{42,43}$ All TIVAD implantations at our unit were performed under fluoroscopy and position of the catheter tips were checked.

Postinterventional bleeding is another minor complication which arises within 24 hours and usually due to coagulation disorders necessitating a local or systemic therapy. ${ }^{31,44}$ In the present study, minor cutaneous bleeding after the TIVAD implantation were noticed in 92 patients and easily managed with local pressure. 
Pocket and entry site hematomas may cause difficulties in palpation of port septum or wound healing due to local tension. Blood and fluid collections may reach huge sizes and needs to be evacuated. It should be noted that a hematoma is also associated with an increased risk for abscess. ${ }^{1}$ In the present study, pocket hematomas were observed in 101 (2.2\%) (RT TIVAD, 72 cases (3.1\%)-LT TIVAD, 29 cases (1.3\%)) TIVAD implantations without any significant wound dehiscence or abscess formation on follow-up. RT TIVAD caused more pocket hematomas due to the larger size of incision and TIVAD pocket.

Catheter dislodgement from the reservoir part of the port is a rare complication. ${ }^{45,46} \mathrm{~A}$ regular check of the TIVAD before each use with the heparinized saline is crucial and specialized nursing care is necessary to prevent irreversible complications associated with subcutaneous antineoplastic agent leakage. In the present study, TIVAD reservoir part and catheter was not connected properly in 1 patient and catheter dislodgement appeared just after its first use.

Infection is a major complication in the early and late period after TIVAD implantation and may be cathegorized as wound/pocket infection, cellulitis and catheter-related blood stream infections. ${ }^{47,48}$ Chemotherapeutics for malignancies definitely suppress the immune system however regimens towards hematologic and gastrointestinal malignancies produce a profound immunosuppression compared to others. There is no consensus about the periprocedural antibiotic prophylaxis in the literature and statistical difference wasn't noted between patients with or without periprocedural antibiotic prophylaxis undergoing TIVAD implantation. ${ }^{47-50}$ However, Gebauer and Da Costa et al concluded that periprocedural antibiotic prophylaxis decreased the risk of infection undergoing pacemaker implantation. ${ }^{51,52}$ In this study, all patients received prophylactic antibiotic before the procedure and were continued up to 3 days.

When there are cutaneous signs of local infection, antibiotic treatment should be immediately started. Empiric antibiotic administration was claimed to prevent TIVAD removal in several cases, however catheter or port related infections are potentially lifethreatening). ${ }^{53,54}$ If there is a doubt of infection in blood or catheter system, serial cultures have to be performed and antibiotic treatment should be started immediately. ${ }^{12}$ TIVADs needed to be removed if infectious processes cannot be controlled or relapsed after treatment. Reported rates of infection after TI-
VAD implantation ranged from $1.1 \%$ to $8.8 \% \%^{9,19,20,40,43}$ In the present study, local or blood stream infections were observed in $75(1.67 \%)$ cases on follow-up and $67(89 \%)$ of these patients responded to antibiotic therapy. Despite aggressive antibiotherapy, 8 patients which had hematological malignancies were lost due to sepsis.

Most important noninfectious complications after TIVAD implantation are deep vein thrombosis and thrombosis of the catheter. In addition to chemotherapy, procoagulant properties of tumor cells, sedentary life style of these patients, endothelial damage of the venous wall secondary to the puncture and dilatation, mechanical irritation of the vascular wall are all known to increase the risk of thrombosis. ${ }^{1,55,56}$ It is clear that endothelial damage and the number of attempted punctures were minimized under the guidance of ultrasonography. ${ }^{56}$ There is no consensus for the prophylactic use of anticoagulants to decrease the thrombosis incidence. ${ }^{16,58,59}$ The reported incidence of TIVADs related thrombosis ranged between 1.06 to $66 \%{ }^{55,60,61}$ When there is a clinical suspicion of deep vein thrombosis based on presence of local swelling, erythrocyanosis, pain and signs of collateral circulation in the limb, an ultrasound examination of the arm should immediately be performed. ${ }^{19,35,61}$ Although ratio of the catheter-associated venous thrombosis was reported up to $66 \%$, few were noted to be symptomatic (3 to $32 \%)^{1,19,41,44,62-65}$ If the patient is asymptomatic and the catheter is functioning, further progression of venous thrombosis may be prevented with anticoagulant therapy without the need of TIVAD removal. ${ }^{1,19,35,61}$ Biffi et al demonstrated that catheterrelated thrombosis was highest on entries through IJV (17.1\%). ${ }^{25}$ However Teichgraber et al pointed out that IJV preference for central venous access was associated with decreased mechanical catheter dysfunctions. ${ }^{19}$ In this study, catheter-associated venous thrombosis was reported in 305 of $4501(6,7 \%)$ patients without any catheter malfunction. Even though all patients with catheter-associated venous thrombosis were subjected to subcutaneous low molecular weight heparin, 47 (1\%) TIVADs were removed because of the progression of the venous thrombosis. In the literature, partial occlusion of the catheter lumen of TIVAD was reported in a range between $6 \%$ and $26 \%$ whereas total occlusion rates were as low as $0.39 \%$ and $1.61 \%$. Infusion of several thrombolytic agents usually provides catheter patency with a success rate of $88 \%{ }^{64}$ TIVAD removal was preferred 
in cases with catheter lumen thrombosis instead of thrombolytic therapy in $62(1.4 \%)$ patients.

Skin perforation is a rare complication that can be seen during the long term follow-up. Factors related to skin perforation are; frequent usage of the TIVAD, TIVAD's reservoir part pressure beneath the skin, narrower TIVAD pocket size and weight loss during the therapy period. In general, three major types of TIVAD are used for central venous access. Miniports are available for pediatric patients and their potential benefit is the decreased size of the septum and catheter thickness. However their use in adult patients are not practical due to difficulty in finding the septum by medical staff and higher risk of thrombosis due to decrease in size of catheter lumen. A LT TIVAD may be defined as an intermediate model between adult regular and pediatric miniports. It is almost identical with the RT TIVAD except its thickness and wideness. LT TIVAD systems may provide ease during implantation and low rate of postprocedural skin perforations. This seems to be most beneficial in patients with cachexy during follow-up. Progressive loss of subcutaneous fat tissue during the course of chemotherapy justified the use of these LT TIVAD'S. ${ }^{68}$ In the present study, LT TIVAD was preferred nearly in half of the patients. Teichgraber et al and Barwińska-Pobłocka et al reported skin perforation rate among 80 and 83 patients as $2.5 \%$ and $2.41 \%$ respectively. ${ }^{68,69}$ The difference between RT and LT TIVADs was studied only in the article by Teichgraber et al. The study presented by Teichgraber et al failed to show difference between low profile and standart probably due to low number of subjects included in their study. In the present study we demonstrated that when the subgroups compared, there was a significant difference between two groups in terms of skin perforation in normal and cachectic patients. Additionally minor hematoma was more common in RT group whereas inversion of TIVAD and venous thrombosis were more common in LT group.

In conclusion, due to the ease of insertion and low risk of skin perforation there is a tendency towards use of LT TIVAD's. This is justified by the favorable results in our large-scale study.

\section{REFERENCES}

1. Walser EM. Venous access ports: indications, implantation technique, follow-up, and complications. Cardiovasc Intervent Radiol 35: 751-764, 2012.
2. Biffi R, de Braud F, Orsi F, et al. Totally implantable central venous access ports for long-term chemotherapy. A prospective study analyzing complications and costs of 333 devices with a minimum follow-up of 180 days. Ann Oncol 9: 767-773, 1998.

3. Broviac JW, Cole JJ, Scribner BH. A silicone rubber atrial catheter for prolonged parenteral alimentation. Surg Gynaecol Obstet 136: 602-606, 1973.

4. Hickman RO, Buckner CD, Clift RA, et al. A modified right atrial catheter for access to the venous system in marrow transplant recipients. Surg Gynecol Obstet 148: 871-875, 1979.

5. Niederhuber JE, Ensminger W, Gyves JW, et al. Totally implanted venous and arterial access system to replace external catheters in cancer treatment. Surgery 92: 706-712, 1982.

6. Reed WP, Newman KA, de Jongh C, et al. Prolonged venous access for chemotherapy by means of the Hickman catheter. Cancer 52: 185-192, 1983.

7. Gebauer B, Teichgräber UK, Podrabsky P, et al. Ultrasoundand fluoroscopy-guided implantation of peripherally inserted central venous catheters (PICCs). Rofo 176: 386-391, 2004.

8. Kock HJ, Pietsch M, Krause U, et al. Implantable vascular access systems: experience in 1500 patients with totally implanted central venous port systems. World J Surg 22: 12-16, 1998.

9. Lorch H, Zwaan M, Kagel C, Weiss HD. Central venous access ports placed by interventional radiologists: experience with 125 consecutive patients. Cardiovasc Intervent Radiol 24: 180-184, 2001.

10. Gallieni M, Pittiruti M, Biffi R. Vascular access in oncology patients. CA Cancer J Clin 58: 323-346, 2008.

11. Kreis H, Loehberg CR, Lux MP, et al. Patients' attitudes to totally implantable venous access port systems for gynecological or breast malignancies. Eur J Surg Oncol 33: 39-43, 2007.

12. Kim JT, Oh TY, Chang WH, Jeong YK. Clinical review and analysis of complications of totally implantable venous access devices for chemotherapy. Med Oncol 29: 1361-1364, 2012.

13. Yip D, Funaki B. Subcutaneous chest ports via the internal jugular vein. A retrospective study of 117 oncology patients. Acta Radiol 43: 371-375, 2002.

14. Dearborn P, De Muth JS, Requarth AB, Ward SE. Nurse and patient satisfaction with three types of venous access devices. Oncol Nurs Forum 24(1 Suppl): 34-40, 1997.

15. Goossens GA, Vrebos M, Stas M, et al. Central vascular access devices in oncology and hematology considered from a different point of view: how do patients experience their vascular access ports? J Infus Nurs 28: 61-67, 2005.

16. Vescia S, Baumgärtner AK, Jacobs VR, et al. Management of venous port systems in oncology: a review of current evidence. Ann Oncol 19: 9-15, 2008.

17. McGee DC, Gould MK. Preventing complications of central venous catheterization. N Engl J Med 348: 1123-1233, 2003.

18. Araújo C, Silva JP, Antunes P, et al. A comparative study between two central veins for the introduction of totally implantable venous access devices in 1201 cancer patients. Eur $J$ Surg Oncol 34: 222-226, 2008.

19. Teichgräber UK, Kausche S, Nagel SN, Gebauer B. Outcome analysis in 3,160 implantations of radiologically guided placements of totally implantable central venous port systems. Eur Radiol 21: 1224-1232, 2011. 
20. Wagner HJ, Teichgräber U, Gebauer B, Kalinowski M. Transjugular implantation of venous port catheter systems. Rofo 175: 1539-1544, 2003.

21. Biffi R, Pozzi S, Agazzi A, et al. Use of totally implantable central venous access ports for high-dose chemotherapy and peripheral blood stem cell transplantation: results of a monocentre series of 376 patients. Ann Oncol 15: 296-300, 2004.

22. Vandoni RE, Guerra A, Sanna P, et al. Randomised comparison of complications from three different permanent central venous access systems. Swiss Med Weekly 139: 313-316, 2009.

23. Sticca RP, Dewing BD, Harris JD. Outcomes of surgical and radiologic placed implantable central venous access ports. Am J Surg198: 829-833, 2009.

24. Chen PT, Sung CS, Wang CC, et al. Experience of anesthesiologists with percutaneous nonangiographic venous access. J Clin Anesth 19: 609-615, 2007.

25. Biffi R, Orsi F, Pozzi S, et al. Best choice of central venous insertion site for the prevention of catheter-related complications in adult patients who need cancer therapy: a randomized trial. Ann Oncol 20: 935-940, 2009.

26. Stein M, Wagner RH. Complications of central venous access devices: outcome analysis of 2359 implantations. Dtsch Med Wochenschr 130: 1129-1132, 2005.

27. Benter T, Teichgräber UK, Klühs L, et al. Anatomical variations in the internal jugular veins of cancer patients affecting central venous access. Anatomical variation of the internal jugular vein. Ultraschall Med 22: 23-26, 2001.

28. Karakitsos D, Labropoulos N, De Groot E, et al. Real-time ultrasound-guided catheterisation of the internal jugular vein: a prospective comparison with the landmark technique in critical care patients. Crit Care 10: R162, 2006.

29. Shabbir J, Kallimutthu SG, O'Sullivan JB, et al. An audit of ultrasound-assisted catheter insertion in patients receiving chemotherapy. Surgeon 3: 32-35, 2005.

30. Teichgräber UK, Benter T, Gebel M, Manns MP. A sonographically guided technique for central venous access. AJR Am J Roentgenol 169: 731-733, 1997.

31. Gebauer B, Teichgräber UM, Werk M, et al. Sonographically guided venous puncture and fluoroscopically guided placement of tunneled, large-bore central venous catheters for bone marrow transplantation-high success rates and low complication rates. Support Care Cancer 16: 897-904, 2008.

32. Akahane $A$, Sone $M$, Ehara $S$, et al. Subclavian vein versus arm vein for totally implantable central venous port for patients with head and neck cancer: a retrospective comparative analysis. Cardiovasc Intervent Radiol 34: 1222-1229, 2011.

33. Nazarian GK, Bjarnason H, Dietz CA Jr, et al. Changes in tunneled catheter tip position when a patient is upright. $\mathrm{J}$ Vasc Interv Radiol 8: 437-441, 1997.

34. Trerotola SO, Kunn-Fulton J, Johnson MS, et al. Tunneled infusion catheters: increased incidence of symptomatic venous thrombosis after subclavian versus internal jugular venous access. Radiology 217: 89-93, 2000.

35. Hinke DM, Zandt-Stastny DA, Goodman LR, et al. Pinch-off syndrome: a complication of implantable subclavian venous access devices. Radiology 177: 353-356, 1990.
36. Mey U, Glasmacher A, Hahn C, et al. Evaluation of an ultrasound-guided technique for central venous access via the internal jugular vein in 493 patients. Support Care Cancer 11: 148-155, 2003

37. Dede D, Akmangit I, Yildirim ZN, et al. Ultrasonography and fluoroscopy-guided insertion of chest ports. Eur J Surg Oncol 34: 1340-1343, 2008.

38. Liberman L, Hordof AJ, Hsu DT, Pass RH. Ultrasound-assisted cannulation of the right internal jugular vein during electrophysiologic studies in children. J Interv Card Electrophysiol 5: 177-179, 2001.

39. De Gregorio MA, Miguelena JM, Fernández JA, et al. Subcutaneous ports in the radiology suite: an effective and safe procedure for care in cancer patients. Eur Radiol 6: 748-752, 1996.

40. Shetty PC, Mody MK, Kastan DJ, et al. Outcome of $350 \mathrm{im}$ planted chest ports placed by interventional radiologists. J Vasc Interv Radiol 8: 991-995, 1997.

41. Gebauer B, El-Sheik M, Vogt M, Wagner HJ. Combined ultrasound and fluoroscopy guided port catheter implantation-high success and low complication rate. Eur J Radiol 69: 517-522, 2009.

42. Petersen J, Delaney JH, Brakstad MT, et al. Silicone venous access devices positioned with their tips high in the superior vena cava are more likely to malfunction. Am J Surg 178: 3841, 1999

43. DeChicco R, Seidner DL, Brun C, et al. Tip position of longterm central venous access devices used for parenteral nutrition. JPEN J Parenter Enteral Nutr 31: 382-387, 2007.

44. Vardy J, Engelhardt K, Cox K, et al. Long-term outcome of radiological-guided insertion of implanted central venous access port devices (CVAPD) for the delivery of chemotherapy in cancer patients: institutional experience and review of the literature. Br J Cancer 91: 1045-1049, 2004.

45. Lemmers NW, Gels ME, Sleijfer DT, et al. Complications of venous access ports in 132 patients with disseminated testicular cancer treated with polychemotherapy. J Clin Oncol 14 2916-2922, 1996.

46. A-Rahman A, Spencer D. Totally implantable vascular access devices for cystic fibrosis. Cochrane Database Syst Rev 5: CD004111, 2003.

47. Douard MC, Arlet G, Longuet $P$, et al. Diagnosis of venous access port-related infections.Clin Infect Dis 29: 1197-202, 1999.

48. Capdevila JA, Planes AM, Palomar M, et al. Value of differential quantitative blood cultures in the diagnosis of catheter-related sepsis. Eur J Clin Microbiol Infect Dis 11: 403-407, 1992.

49. Marcy PY, Magné N, Castadot P, et al. Radiological and surgical placement of port devices: a 4-year institutional analysis of procedure performance, quality of life and cost in breast cancer patients. Breast Cancer Res Treat 92: 61-67, 2005.

50. Goltz JP, Schmid JS, Ritter CO, et al. Identification of risk factors for catheter-related thrombosis in patients with totally implantable venous access ports in the forearm. $J$ Vasc Access 13: 79-85, 2012.

51. Gebauer B, Teichgräber U, Werk M, Wagner HJ. Periinterventional prophylactic antibiotics in radiological port catheter implantation. Rofo 179: 804-810, 2007. 
52. Da Costa A, Kirkorian G, Chevalier P, et al. Infections secondary to implantation of cardiac pacemakers. Arch Mal Coeur Vaiss 91: 753-757, 1998.

53. Imberti D, Di Nisio M, Donati MB, et al. Treatment of venous thromboembolism in patients with cancer: Guidelines of the Italian Society for Haemostasis and Thrombosis (SISET). Thromb Res 124: 32-40, 2009.

54. Bouza E, Burillo A, Muñoz P. Catheter-related infections: diagnosis and intravascular treatment. Clin Microbiol Infect 8: 265274, 2002

55. De Cicco M, Matovic M, Balestreri L, et al. Central venous thrombosis: an early and frequent complication in cancer patients bearing long-term silastic catheter. A prospective study. Thromb Res 86: 101-113, 1997.

56. Balestreri L, De Cicco M, Matovic M, et al. Central venous catheter-related thrombosis in clinically asymptomatic oncologic patients: a phlebographic study. Eur J Radiol 20: 108111, 1995.

57. Machi J, Takeda J, Kakegawa T. Safe jugular and subclavian venipuncture under ultrasonographic guidance. Am J Surg 153: 321-323, 1987.

58. Minassian VA, Sood AK, Lowe P, et al. Longterm central venous access in gynecologic cancer patients. . J Am Coll Surg 191: 403-409, 2000.

59. Bif $\mathrm{R}$, De Braud F, Orsi F, et al. A randomized, prospective trial of central venous ports connected to standard open-ended or Groshong catheters in adult oncology patients. Cancer 92: 1204-1212, 2001.

60. Cortelezzi A, Moia M, Falanga A, et al. CATHEM Study Group. Incidence of thrombotic complications in patients with haematological malignancies with central venous catheters: a prospective multicentre study. Br J Haematol 129: 811-817, 2005.

61. Beckers MM, Ruven HJ, Seldenrijk CA, et al. Risk of thrombosis and infections of central venous catheters and totally implanted access ports in patients treated for cancer. Thromb Research 125: 318-321, 2010.

62. Sakamoto N, Arai Y, Takeuchi Y, et al. Ultrasound-Guided Radiological Placement of Central Venous Port via the Subclavian Vein: A Retrospective Analysis of 500 Cases at a Single Institute. Cardiovasc Intervent Radiol 33: 989-994, 2010.
63. Ozdemir NY, Abali H, Oksüzoglu B, et al. It appears to be safe to start chemotherapy on the day of implantation through subcutaneous venous port catheters in inpatient setting. Support Care Cancer 17: 399-403, 2009.

64. Odabas H, Ozdemir NY, Ziraman I, et al. Effect of port-care frequency on venous port catheter-related complications in cancer patients. Int J Clin Oncol 2013 Aug 27. [Epub ahead of print]

65. Owens CA, Bui JT, Knuttinen MG, et al. Pulmonary embolism from upper extremity deep vein thrombosis and the role of superior vena cava filters: a review of the literature. J Vasc Interv Radiol 21: 779-787, 2010.

66. Daeihagh P, Jordan J, Chen J, Rocco M. Efficacy of tissue plasminogen activator administration on patency of hemodialysis access catheters. Am J Kidney Dis 36: 75-79, 2000.

67. Ruschulte H, Franke M, Gastmeier P, et al. Prevention of central venous catheter related infections with chlorhexidine gluconate impregnated wound dressings: a randomized controlled trial. Ann Hematol 88: 267-272, 2009.

68. Teichgräber UK, Streitparth $\mathrm{F}$, Cho $\mathrm{CH}$, et al. A comparison of clinical outcomes with regular- and low-profile totally implanted central venous port systems. Cardiovasc Intervent Radiol 32: 975-979, 2009.

69. Barwinska-Poblocka K, Wydra D, Abacjew-Chmylko A, Szkop-Dominiak A. The use of venous ports in oncological patients. Ginekol Pol 84: 339-343, 2013.

\section{Correspondance}

Dr. Illkay AKMANGiT

1473. Cadde No: 13

Gölbașı, ANKARA / TURKEY

Tel: (+90.532) 5136604

Fax: (+90.312) 3103460

e-mail: ilkayakm@hotmail.com 